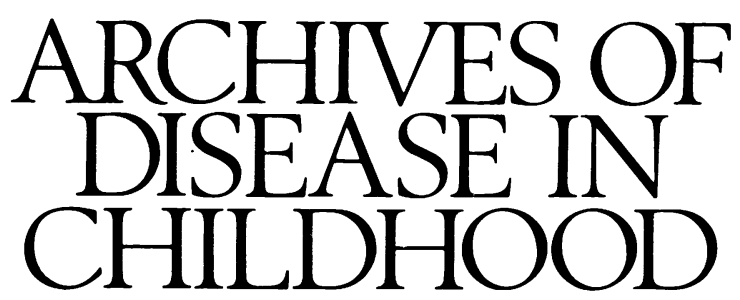

The fournal of the British Paediatric Association

\title{
Professor Dame June Lloyd
}

The James Spence Medal was presented to Professor June Lloyd on 21 April 1993. Professor Sir David Hull, President of the British Paediatric Association, gave the following citation.

The James Spence Medal is awarded at the recommendation of the Council of the British Paediatric Association for outstanding contributions to the advancement of paediatric knowledge. It is my pleasure this year to present it to June Kathleen Lloyd.

It seems appropriate that Professor Dame June Lloyd should have been born on January the First. She gained scholarships and prizes during her student days at the medical school in Bristol where she qualified with honours, and 40 years later the University of Bristol recognised her continuing excellence by awarding her an Honorary DSc. She 'lingered' as a house officer for three years and gained membership of the Royal College of Physicians of London of which she is currently a Vice President. After two years as a paediatric registrar she went to study for the Diploma of Public Health in the University of Durham whose medical faculty was in neighbouring Newcastle upon Tyne. It was clearly a smart move, but it was not as fashionable then as its equivalent is now. However, Newcastle - the home of James Spence - must have given unrivalled opportunities to study child health.

Then she moved to Birmingham where Otto Wolff was a senior lecturer. Thus began a fruitful collaboration which was to last for many years. First as a research fellow, then as a lecturer in Birmingham she began her studies on nutrition and in particular the role of lipid metabolism in health and disease in childhood. It is difficult to appreciate now how novel and difficult it was in 1960 to investigate lipid metabolism. The central role of free fatty acids in the transfer of energy was only just being appreciated and technically lipid metabolism was very difficult to investigate.

I am told she became interested in vitamin $E$ when she was a senior research fellow on a Wellcome Research Travel grant studying at Washington University, USA. At that time

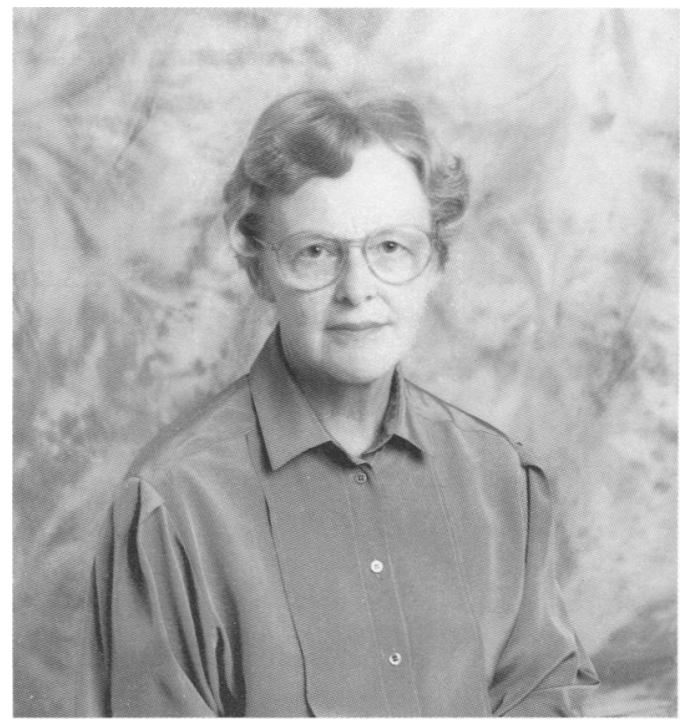

vitamin E, unlike June, did not enjoy a respectable reputation. Many doubted that it had a claim to be called a vitamin, and there was general uncertainty about its biological function. June returned with a supply in her baggage, for she had a use for it. Subsequently she was to demonstrate that neurological damage to patients with a rare metabolic disease, $\alpha$-betalipoproteinaemia, could be avoided by administration of vitamin $E$. Her fascination with vitamin $\mathrm{E}$ has endured. Those who have heard her describe its wider functions enter a world of chemicals, with strange names like tocopherol, which act as 'antioxidants' which sounds unhelpful.

When Otto Wolff moved to become professor of child health at the Institute of Child Health in London, June Lloyd was appointed senior lecturer and honorary consultant physician to the Hospital for Sick Children, Great Ormond Street. Her task was not only to provide specialist clinical services for children with metabolic diseases but also to establish within the institute a research laboratory for the investigation of children with metabolic disorders. Many of her scientific papers and clinical reviews are based on the fruitful linkage between the service and 
laboratory. Her clinical expertise was quickly recognised and children with lipid disorders were referred from around the country.

But her interest in nutrition was far wider than the dietary management of rare metabolic disorders. In 1976 she wrote two reviews in Recent Advances in Paediatrics, the first on obesity with Otto Wolff, the second on hyperlipoproteinaemia and atherosclerosis. These are two of the major health problems of our times, and they reap their revenge by reducing longevity rather than ruining childhood. That she was writing reviews on both of them in 1976 illustrates not only her wider interests but also something that has always been the case but is easily overlooked, and that is that the Institute of Child Health and Hospital for Sick Children have never been concerned solely with the immediate care of the ill child with a difficult disease, though that has been their first duty. June Lloyd's published work illustrates her considerable contribution to our current understanding on both problems.

Then as now, everything in the health service was under review, committees met, reports had to be prepared. The department of paediatrics in the institute had much to do with teaching and research as well as service. Expansion was in the air. Late one spring evening in the boardroom of Great Ormond Street a group of us were meeting, there was a need for a detailed report, it was already May, and someone said it would have to be done by June. Otto frowned, he knew the pressures on his department, and firmly and politely as is his style, said he did not think that June would have the time. In Otto's mind June was never a month of the year!

When St George's Hospital closed its site at Hyde Park Corner and moved to the new medical school in Tooting, Professor Lloyd was appointed head of the department for child health. There she established a new academic department in child health appropriate for our times.

Her industry and ability led to her being in great demand for committee work. It would perhaps be easier to list those committees on which she has not served, or those paediatric societies in the world of which she is not a member. Her fair, firm, forthright approach has been greatly appreciated by those responsible for managing our universities, research councils, charities, and health services. She was BPA President from 1988 to 1991. Her achievements have been recognised by her being invited to give named lectures, to receive honorary degrees, and by being honoured by the Queen.

\section{James Spence Medallists}

1960 Professor A A Moncrieff 1961 Professor R A McCance 1963 Sir F Macfarlane Burnet 1964 Professor L S Penrose 1965 Dr Cicely D Williams 1967 Professor R R A Coombs 1968 Dr Mary Sheridan Dr D W Winnicott 1969 Dr G S Dawes 1970 Professor D V Hubble 1971 Dr W W Payne 1972 Dr R C MacKeith 1973 Professor C A Clarke 1974 Dr J Bowlby 1976 Dr D M T Gairdner 1977 Professor R S Illingworth
1978 Professor S D M Court

1979 Professor K W Cross

1980 Professor J M Tanner

1981 Dr Elsie $M$ Widdowson

1982 Dr D MacCarthy

1983 Professor J O Forfar

1984 Dr J W B Douglas

1985 Dr N S Gordon

1986 Sir Peter Tizard

1987 Professor J L Emery Dr F J Miller

1988 Professor O H Wolff

1989 Professor D C Morley

1990 Professor L B Strang

1991 Professor John A Davis

1992 Professor Richard W Smithells 